\title{
Epidemiology of Plasma Cell Leukemia in the Czech Republic
}

\section{Epidemiologie plazmocelulární leukemie v České republice}

\author{
Zapletalova M. ${ }^{2}$, Krejci D. ${ }^{1,2}$, Jarkovsky J. ${ }^{1,2}$, Muzik J. ${ }^{1,2}$, Dusek L. ${ }^{1,2}$ Pour L. ${ }^{3}$ \\ ${ }^{1}$ Institute of Biostatistics and Analyses, Faculty of Medicine, Masaryk University, Brno \\ ${ }^{2}$ Institute of Health Information and Statistics of the Czech Republic, Prague \\ ${ }^{3}$ Department of Internal Medicine, Hematology and Oncology, University Hospital Brno
}

\begin{abstract}
Summary
Background: Plasma cell leukemia (PCL) is a rare but most aggressive form of monoclonal gammopathies. PCL is characterized by the presence of clonal plasma cells in peripheral blood. There are two forms of $\mathrm{PCL}$ - primary which presents de novo in patients with no evidence of previous multiple myeloma and secondary which is a leukemic transformation of relapsed or refractory disease in patients with previously recognized multiple myeloma. Materials and methods: This is the first study to provide information on PCL epidemiology in the Czech population using The Czech National Cancer Registry (CNCR) as the basic source of data for the population-based evaluation of PCL epidemiology. Results: According to CNCR data, there were on average six newly diagnosed cases of PCL and four deaths caused by PCL each year in the Czech Republic in the period 2000-2015. PCL incidence in the Czech Republic was reported at 0.57 per million in 2000-2015. We suppose that most reported cases of PCL are primary $\mathrm{PCL}$ because secondary PCL is a relapse of a previously reported myeloma and, in most cases, is not coded as an independent diagnosis in the CNCR. Conclusion: Data from registries such as the CNCR can provide useful information on epidemiology of various diseases. These data, however, have several limitations, such as diagnostic criteria and proper coding of not only the disease itself, but also its various forms. These limitations have to be taken into account during the process of results interpretation.
\end{abstract}

\section{Key words}

plasma cell leukemia - epidemiology - Czech National Cancer Registry (CNCR) - Czech Republic

\section{Souhrn}

Východiska: Plazmocelulární leukemie (PCL) je vzácná, ale velmi agresivní forma monoklonální gamapatie. $\mathrm{PCL}$ je charakterizována prítomností klonálních plazmatických buněk v periferní krvi. PCL existuje ve dvou formách, přičemž primární $\mathrm{PCL}$ vzniká de novo u pacientů bez jakéhokoliv záznamu o předchozím mnohočetném myelomu, zatímco sekundární PCL vzniká leukemickou transformací při relapsu nebo refrakterním onemocnění u pacientů s dřive diagnostikovaným mnohočetným myelomem. Materiál a metody: Prezentovaná publikace je první studií poskytující informace o epidemiologii PCL v české populaci využívající Národní onkologický registr (NOR) jako základní zdroj populačního hodnocení epidemiologie PCL. Výsledky: Dle dat NOR je v období 2000-2015 každoročně průměrně diagnostikováno šest nových prípadů $P C L$ a z důvodu $P C L$ dochází ke čtyřem úmrtím ročně. Incidence $P C L$ v České republice je $v$ tomto období 0,57 prípadu na milion obyvatel. U většiny zaznamenaných případů $P C L$ jde pravděpodobně o primární $P C L$, protože sekundární $P C L$, která je relapsem dřive zaznamenaného myelomu, není obvykle v datech NOR kódována jako samostatná diagnóza. Závěr: Data z populačních registrů jako je NOR mohou poskytovat užitečné informace o epidemiologii různých onemocnění. Tento typ dat má nicméně určité limitace, jako jsou např. problémy vyplývající z diagnostických kritérií onemocnění, jejich změn v čase a korektního kódování nejenom vlastních onemocnění, ale i jejich různých forem. Tyto limitace musí být vzaty do úvahy během interpretace výsledků epidemiologických analýz.

\section{Klíčová slova}

plazmocelulární leukemie - epidemiologie - Národní onkologický registr (NOR) - Česká republika
The publication was supported by the ESF project CZ.03.4.74/0.0/0.0/15_019/0002748 Development of NZIS technological platform.

Tato práce byla podpořena projektem ESF CZ.03.4.74/0.0/0.0/15_019/0002748 Rozvoj technologické platformy NZIS.

The authors declare they have no potential conflicts of interest concerning drugs, products, or services used in the study.

Autoři deklaruji, že $v$ souvislosti s predmětem studie nemaji žádné komerční zájmy.

The Editorial Board declares that the manuscript met the ICMJE recommendation for biomedical papers.

Redakční rada potvrzuje, že rukopis práce splnil ICMJE kritéria pro publikace zasílané do biomedicínských časopisů.

RNDr. Jiří Jarkovský, Ph.D. Institute of Biostatistics and Analyses Faculty of Medicine Masaryk University Kamenice 126/3 62500 Brno

Submitted/Obdrženo: 3. 1. 2019 Accepted/Přijato: 22. 1. 2019

doi: 10.14735/amko201947 


\section{Introduction}

The importance of cancer epidemiology has been growing steadily, partly due to the growing cancer burden worldwide. The Czech Republic is no exception in this regard; in fact, it is one of the countries with the highest burden of several cancer types. Tens of thousands of cancer patients are newly diagnosed in the Czech Republic each year, and hundreds of thousands of them are followed up due to a history of cancer in the past [1]. This work aims to describe the epidemiological situation as well as epidemiological trends of plasma cell leukemia $(\mathrm{PCL})$, which is a rare but the most aggressive form of monoclonal gammopathies. PCL is defined by the presence of more than $20 \%$ of plasma cells in the peripheral blood or the absolute plasma cell count $>2 \times 109 / \mathrm{L}$ [2]. PCL is classified as primary ( $\mathrm{pPCL}$ ) when it presents de novo in patients with no evidence of previous multiple myeloma (MM) and as secondary ( $\mathrm{SPCL}$ ) when it is observed as a leukemic transformation of relapsed or refractory disease in patients with previously recognized MM [3]. About $60-70 \%$ of $P C L$ are $p P C L$, whereas the remaining $30-40 \%$ are $\mathrm{SPCL}$ [4].

\section{Materials and Methods}

High-quality data play a key role in the evaluation of cancer epidemiology; in particular, the following two data sources [5] are used for this purpose in the Czech Republic.

First, data on demographic structure of the population of the Czech Republic are processed by the Czech Statistical Office (CZSO) as part of its monitoring activities. These data cover demographic characteristics of the population, such as the total population size, age structure, life expectancy etc. $[6,7]$. Population-based data on cancer mortality are stored in a database of causes of death, which is also processed by the CZSO in accordance with international methodology and based on data from death certificates (ICD-10 classification).

Second, the Czech National Cancer Registry (CNCR) is the main source of data on cancer epidemiology. Nowadays, the CNCR is an integral part of comprehensive cancer care, covering $100 \%$ of the Czech population and containing more than 2.3 million cancer cases recorded between 1977 and 2015. According to CNCR data, the lifetime risk of developing cancer is approximately $1 / 3$ in the Czech population. However, $\mathrm{PCL}$ is a very rare disease that only accounts for $0.02 \%$ of these records. In general, the registration of malignant tumors is enshrined in the Czech legislation and is obligatory. The CNCR is also the source of data for the assess-

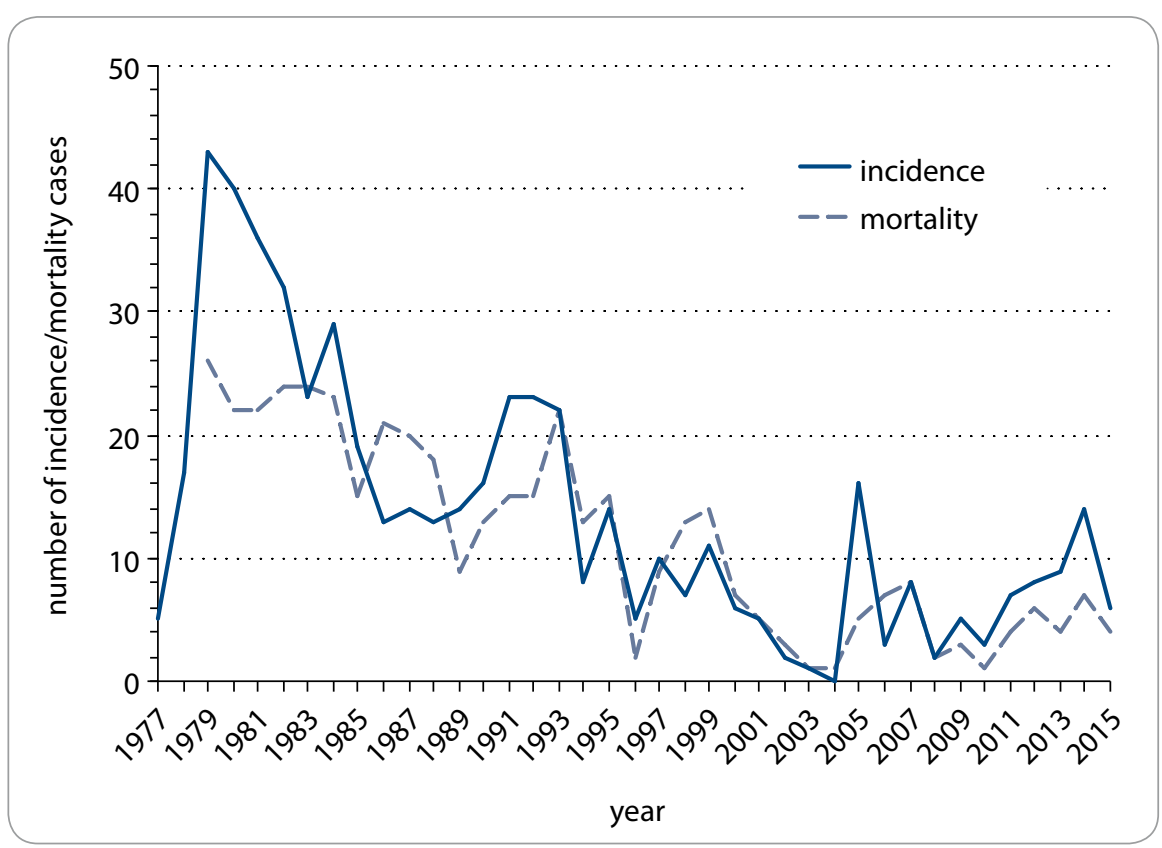

Graph 1. Trends in plasma cell leukemia incidence and mortality - absolute numbers [7]. ment of basic performance indicators of cancer care, particularly for the assessment of patient survival. The Czech Society for Oncology has used CNCR data to develop an information system that predicts not only the population burden of cancer, but also treatment burden for future periods. Predictions of the population burden of cancer are based on modelling of the development of demographic structure and cancer incidence in the population. On the other hand, predictions of prevalence of cancer patients to be treated in the near future are based on survival models. The methodology and applied prediction scenarios are described in Dusek et al. [1].

\section{Results}

International comparison

of PCL epidemiology

Due to relatively low incidence and prevalence rates of $\mathrm{PCL}$, international epidemiological data are not available in commonly used databases, such as the GLOBOCAN database (http://gco.iarc. $\mathrm{fr} /$ ). Epidemiological estimates are therefore based on isolated studies. PCL is usually diagnosed in $2-4 \%$ of MM patients [8,3-10]; this is consistent with our results from the CNCR (1977-2015), where the ratio of $P C L$ to $M M$ patients is $3: 100$.

\section{Epidemiology of MM}

in the Czech Republic

For the purpose of analysis of CNCR data, neoplasms with diagnosis C90.1 (according to the International Statistical Classification of Diseases and Related Health Problems - 10th Revision, ICD-10) and neoplasms with morphology code 9733/3 (according to the International Classification of Diseases for Oncology $3^{\text {rd }}$ Edition, ICD-O-3) were included in the group of PCL. Nevertheless, available data do not distinguish between $\mathrm{PPCL}$ and $\mathrm{SPCL}$; most cases of $\mathrm{SPCL}$ are therefore probably included under MM in CNCR data and cannot be distinguished as an independent diagnosis.

Trends in PCL incidence and mortality in the Czech Republic over more than three decades are shown in Graph 1. Both incidence and mortality rates decreased until approximately the year 
2000 and have stabilized since then. The average annual incidence was 19 patients in the period 1997-1999, and 6 patients in the period 2000-2015. This downward trend can be probably attributed to diagnostics and coding issues of this rare diagnosis. In absolute numbers, the incidence in 2015 was 6 persons (0.57 per million population), namely 5 men and 1 woman. In terms of mortality, 4 persons ( 0.38 per million population) died from $P C L$ in 2015 , all of them were men. The overall epidemiological situation regarding $P C L$ in the Czech Republic is summarized in Tab. 1. Data from the CNCR have shown that $4.5 \%$ of $P C L$ cases $(14.7 \%$ in the period 2000-2015) were preceded by another cancer in the same patient.

The proportion of men and women with PCL was approximately the same. We have confirmed that PCL is mostly diagnosed in older people - the median age was 66 years in men and 70 years in women, which is consistent with the median age of MM patients. Incidence rates were highest between the ages of 70 and 74 years in men and between the ages of 70 and 79 years in women (Graph 2). At the time of diagnosis, around $2 \%$ of all $P C L$ patients were under the age of 45 , and approximately $25 \%$ of all MM patients were under the age of 60 . Agespecific incidence rates rise sharply from around the age of 45 (Graph 2) and thus demonstrate the growing risk of developing PCL in older age.

Graph 3 shows the comparison of $\mathrm{PCL}$ incidence in regions of the Czech Republic in the period 1977-2015. Prague (capitol of the (zech Republic) reported the highest incidence of PCL (2.09 cases per million per year), whereas the Olomouc Region and the South Moravian Region had the lowest incidence (both regions reported 0.52 cases per 1 million per year).

\section{Discussion}

The epidemiology of rare diseases from CNCR data should be interpreted carefully, with awareness of data limitations. The quality of coding of rare diagnoses is closely related to diagnostics of the disease and the overall awareness of the disease. In general, there are two

Tab. 1. Basic epidemiological characteristics of plasma cell leukemia in the Czech Republic [7].

\section{Men Women Total}

\section{Incidence}

absolute number of newly diagnosed cases

\begin{tabular}{|l|c|c|c|}
\hline $1977-2015$ & 270 & 262 & 532 \\
\hline $2000-2015$ & 49 & 46 & 95 \\
\hline 2015 & 5 & 1 & 6 \\
\hline
\end{tabular}

number of new cases per 1 million population

\begin{tabular}{|c|c|c|c|}
\hline 2000-2015 & 0.60 & 0.54 & 0.57 \\
\hline 2015 & 0.97 & 0.19 & 0.57 \\
\hline rend in 2000-2015 & $+61 \%$ & $-26 \%$ & $+18 \%$ \\
\hline ypical age (median; $25-75^{\text {th }}$ percentile; $1977-2015$ ) & $\begin{array}{c}66 ; \\
58-74\end{array}$ & $\begin{array}{c}70 \\
60-76\end{array}$ & $\begin{array}{c}68 \\
59-75\end{array}$ \\
\hline nen : women (1977-2015) & - & - & $1.1: 1$ \\
\hline
\end{tabular}

\section{Mortality}

absolute number of deaths

\begin{tabular}{|l|c|c|c|}
\hline $\begin{array}{l}\text { 1977-2015 } \\
\text { 2000-2015 }\end{array}$ & 32 & 36 & 68 \\
\hline 2015 & 4 & 0 & 4 \\
\hline number of deaths per 1 million population & & & \\
\hline $2000-2015$ & 0.39 & 0.42 & 0.41 \\
\hline 2015 & 0.77 & 0.00 & 0.38 \\
\hline trend in 2000-2015 & $-60 \%$ & $-51 \%$ & $-57 \%$ \\
\hline proportion of mortality/incidence (2000-2015) & 0.65 & 0.78 & 0.72 \\
\hline
\end{tabular}

Plasma cell leukemia definition - neoplasms with diagnosis C90.1 or neoplasms with morphology code 9733/3.

problems with PCL coding in a population-based registry, such as the CNCR. First, the disease is classified into two forms - $\mathrm{PPCL}$, which occurs without previously identified $M M$ stage, and $S P C L$, which develops from previously diagnosed and treated MM [11]. We suppose that most reported cases of $\mathrm{PCL}$ are $\mathrm{PPCL}$ because $\mathrm{SPCL}$ is a relapse of a previously reported myeloma and in most cases, is not coded as an independent diagnosis in the CNCR. More recent data suggest that the incidence of SPCL has increased, now accounting for about $50 \%$ of the cases [12]; this might also influence the results. Second, the development of diagnostic criteria and laboratory techniques can influence the classification of PCL patients and therefore also the recorded epidemiology of the disease. The first diagnostic criteria were defined in 1974 [13] and amended in 1987 [14]. The current diagnostic criteria, which originated in the 1970s, might underestimate the prevalence of $P C L$, and their re-evaluation is therefore being considered [2].

Data from registries, such as the CNCR, can provide useful information on epidemiology of various diseases. These data, however, have several limitations, such as diagnostic criteria and proper coding of not only the disease itself, but also its various forms. These limitations have to be taken into account during the process of results interpretation. 


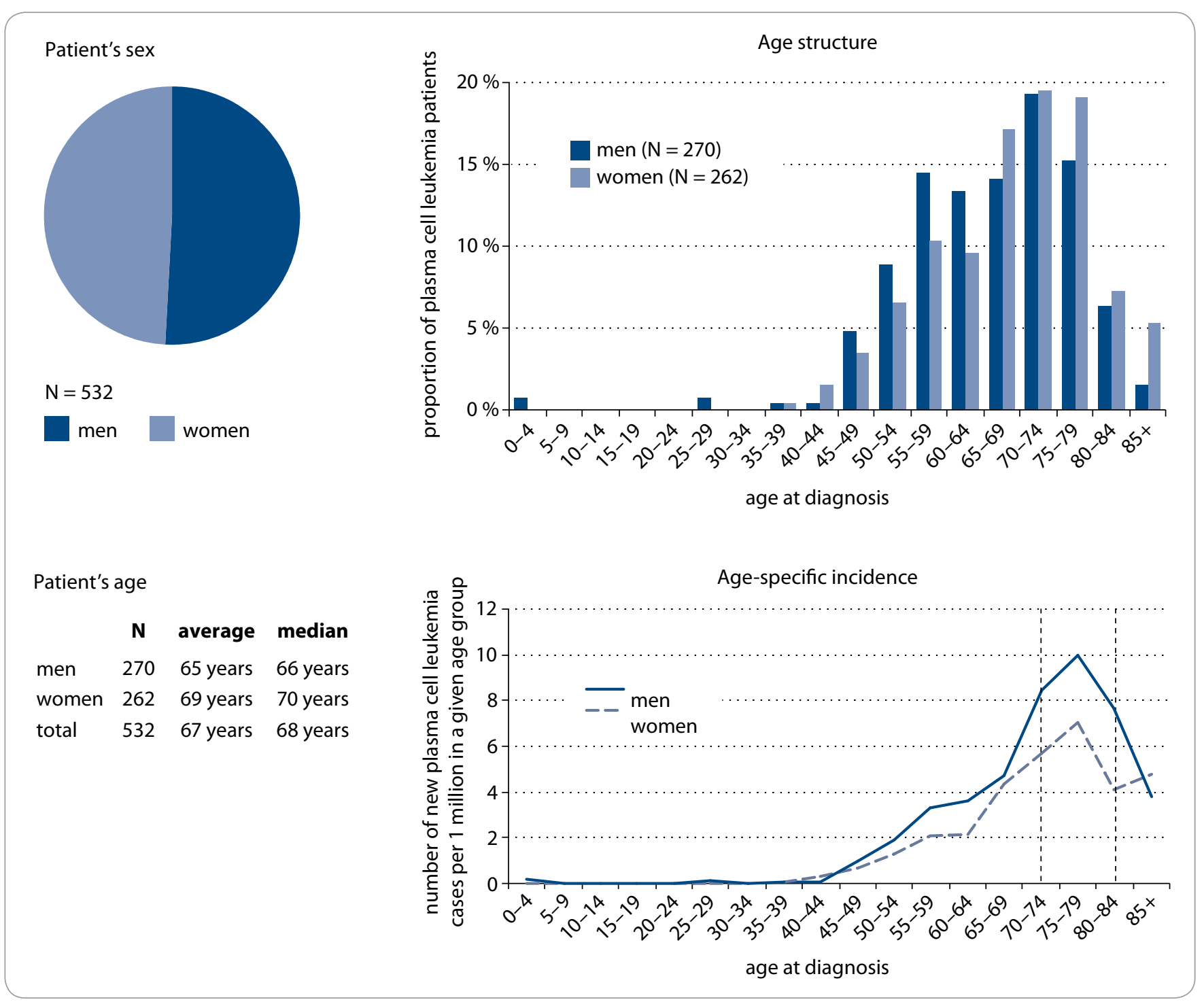

Graph 2. Age and sex of plasma cell leukemia patients in the period 1977-2015.

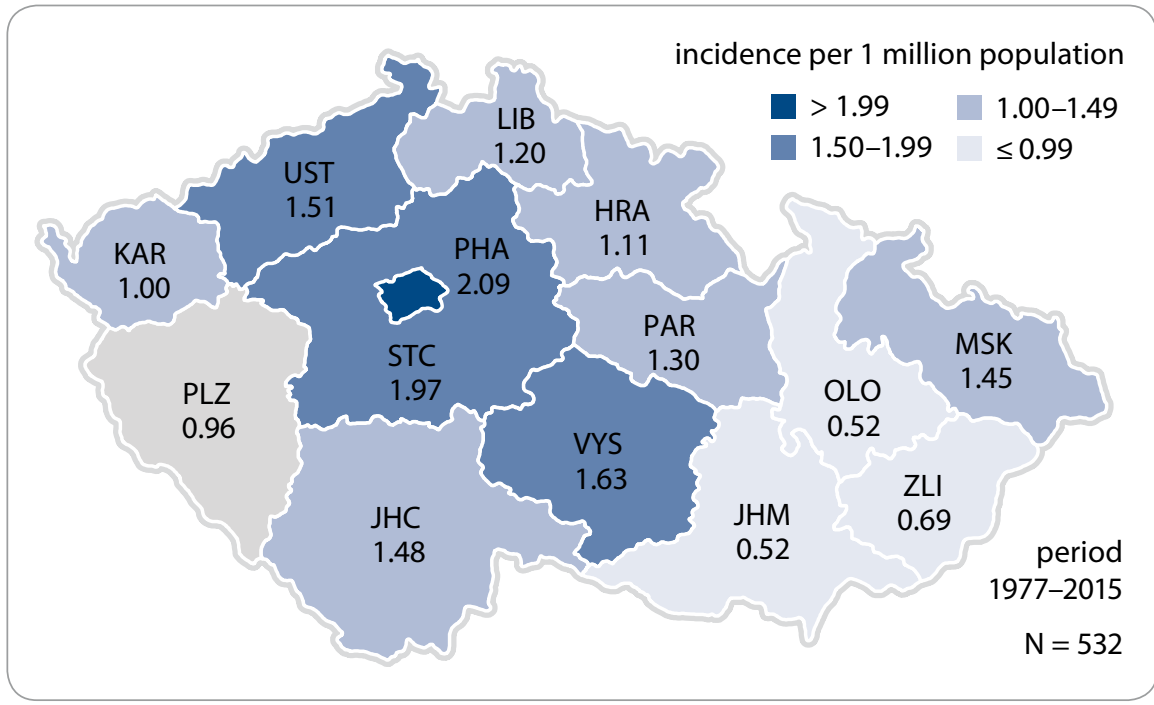

Graph 3. Regional incidence of plasma cell leukemia.

\section{Conclusion}

The aim of this work was to describe the epidemiological situation as well as epidemiological trends of plasma cell leukemia. In the Czech Republic, an average of 6 people were newly diagnosed with $\mathrm{PCL}$ and about 4 people died from it between 2000 and 2015 each year. The ratio of PCL to MM patients is $3: 100$, which is a result comparable to international data.

\section{References}

1. Dušek L (ed). Czech cancer care in numbers 2008-2009. Praha: Grada Publishing 2009.

2. Fernández de Larrea C, Kyle RA, Durie BG et al. Plasma cell leukemia: consensus statement on diagnostic requirements, response criteria and treatment recommendations by the International Myeloma Working Group. Leukemia 2013; 27(4): 780-791. doi: 10.1038/leu.2012.336. 
3. García-Sanz R, Orfão A, González M et al. Primary plasma cell leukemia: clinical, immunophenotypic, DNA ploidy, and cytogenetic characteristics. Blood 1999; 93(3): 1032-1037.

4. Bladé J, Kyle RA. Nonsecretory myeloma, immunoglobulin D myeloma, and plasma cell leukemia. Hematol Oncol Clin North Am 1999; 13(6): 1259-1272.

5. Dušek L, Žaloudík J, Indrák K. Informační zázemí pro využití onkologických populačních dat v ČR. Klin Onkol 2007; 20 (Suppl 1): 52-196.

6. Český statistický úřad. Demografická príručka 2016 [online]. Dostupné z: https://www.czso.cz/csu/czso/demograficka-prirucka-2016.
7. Ústav zdravotnických informací a statistiky ČR. Národn zdravotnický informační systém (NZIS), Národní onkologický registr (NOR). [online]. Dostupné z: http://www.uzis $\mathrm{cz/registry-nzis/nor.}$

8. Dimopoulos MA, Palumbo A, Delasalle KB et al. Primary plasma cell leukaemia. Br J Haematol 1994; 88(4):754-759. 9. Ramsingh G, Mehan P, Luo J et al. Primary plasma cell leukemia: a surveillance, epidemiology, and end results database analysis between 1973 and 2004. Cancer 2009; 115(24): 5734-5739. doi: 10.1002/cncr.24700.

10. Tiedemann RE, Gonzalez-Paz N, Kyle RA et al. Genetic aberrations and survival in plasma cell leukemia. Leukemia 2008; 22(5): 1044-1052. doi: 10.1038/leu 2008.4.
11. International Myeloma Working Group. Criteria for the classification of monoclonal gammopathies, multiple myeloma and related disorders: a report of the International Myeloma Working Group. Br J Haematol 2003; 121(5): 749-757.

12. Tiedemann RE, Gonzalez-Paz N, Kyle RA et al. Genetic aberrations and survival in plasma cell leukemia. Leukemia 2008; 22(5): 1044-1052. doi: 10.1038/leu.2008.4.

13. Kyle RA, Maldonado JE, Bayrd ED. Plasma cell leukemia. Report on 17 cases. Arch Intern Med 1974; 133(5): 813-818.

14. Noel P, Kyle RA. Plasma cell leukemia: an evaluation of response to therapy. Am J Med 1987; 83(6): 1062-1068. 